\title{
Distributed modelling of water resources and pollute transport in Malwathu Oya Basin, Sri Lanka
}

\author{
A.C. Dahanayake* and R.L.H.L. Rajapakse \\ Department of Civil Engineering, Faculty of Engineering, University of Moratuwa, Katubedda, Moratuwa.
}

\begin{abstract}
The Nachchaduwa sub-catchment (598.74 $\mathrm{km}^{2}$ ) of the Malwathu Oya basin is seasonally stressed in the dry periods and its downstream parts undergo intermittent floods during monsoon seasons while the fate and behaviour of excess nitrogen $(\mathrm{N})$ and phosphorus $(\mathrm{P})$ added to the waterways due to agricultural fertilisers used in the upstream areas remain unresolved. This study incorporated the Water and Energy Transfer Processes (WEP) model to assess the present status of the catchment concerning water resources and pollutant transport. Results showed that the catchment response to the rainfall is highly regulated due to reservoir storage effect (ungauged basin with regulated flows). The amounts of $\mathrm{N}$ and $\mathrm{P}$ in fertilisers applied in this catchment exceeded the actual plant requirement. In both wet [Maha cultivation season (October to March)] and dry [Yala cultivation season (April to September)] seasons, the differences between the upstream and downstream values of measured water quality parameters $(\mathrm{N}$ and $\mathrm{P}$ components - total, dissolved and particulate) in waterways were not statistically significant. On average, the wet season had about 5 7 times the dry season value of the total suspended solids (TSS) in the streams, and in both seasons, the modelled TSS, $\mathrm{NO}_{3}^{-}$and $\mathrm{PO}_{4}^{3-}$ were within the ranges of the previously published results. This study will be continued in the future to analyse possible hydrological and material transport related scenarios to identify best water resources management practices and to pragmatically cope with the excess fertiliser usage, an issue commonly found in most of the similar catchments.
\end{abstract}

Keywords: Nachchaduwa, nitrogen, nutrient concentrations, phosphorus, TSS, WEP model.

\section{INTRODUCTION}

Water, being a vital natural resource to sustain all life forms on earth, has now become a limited resource due to the adverse impacts of various natural and anthropogenic causes. Due to the increasing population and rapid urbanisation, the demand for water has been increasing drastically. Further, the quality of the available fresh water resources has been deteriorating mainly due to pollution created by the anthropogenic activities in many rivers in developing countries, which has become a threat to the ecosystem and to human health.

Malwathu Oya basin is the second largest catchment among the river basins in Sri Lanka $\left(3284 \mathrm{~km}^{2}\right)$, and one of the most widely used sources of water for irrigation, water supply and other diversions in the North Central Province (Figure 1). It has now become a seasonally stressed river basin due to over exploitation and water pollution. The basin experiences water scarcity during the dry periods and the downstream areas of the catchment are flooded during the wet periods, whilst severe flooding was observed in 2011, 2014 and 2016 (Department of Irrigation, unpublished data).

The basin is augmented by the adjacent Kala Oya basin from Kala Wewa reservoir via Yoda Ela to

\footnotetext{
*Corresponding author (amalidahanayake@yahoo.com; (iD https://orcid.org/0000-0002-4400-6979)
} 


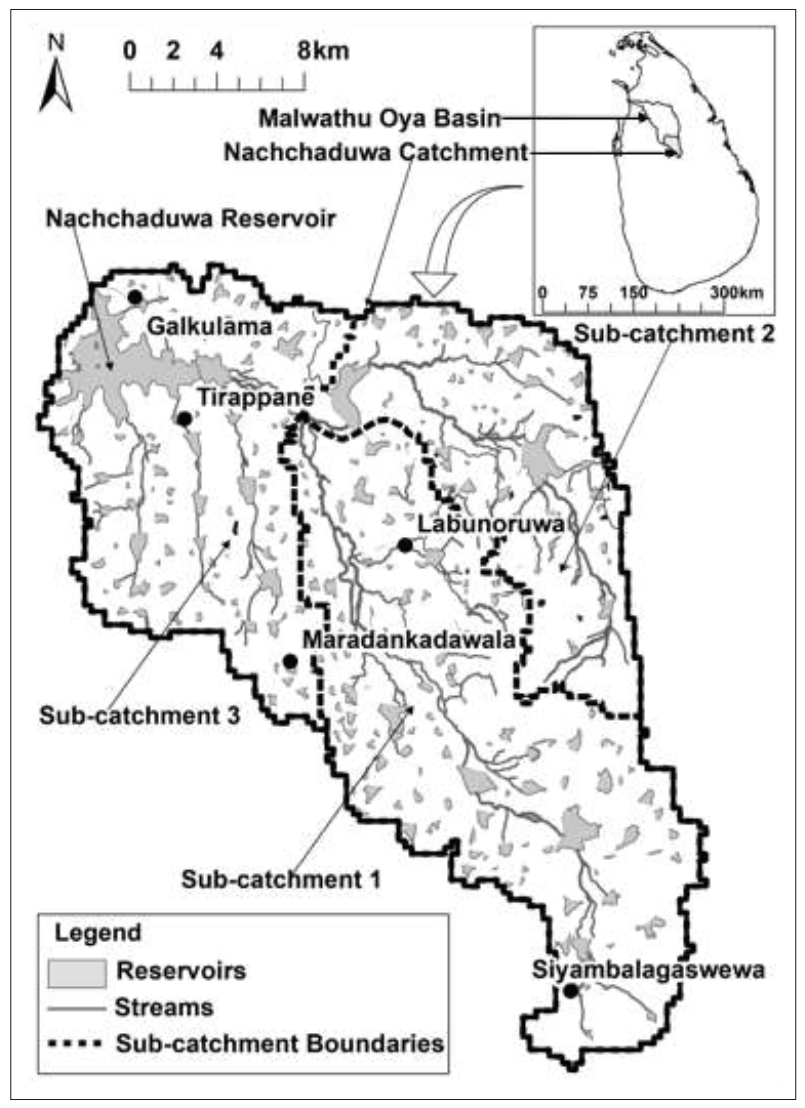

Figure 1: Nachchaduwa catchment and the delineation of sub-catchments

feed Nachchaduwa, Tissa wewa and Basawakkulama reservoirs. The basin is distinct as it possesses a large number of tanks, from small size village tanks to comparatively fair-sized tanks, from which the rainfall runoff process is largely influenced. Up to a certain threshold, the river flow is more or less regulated and flood peaks are reduced (Department of Irrigation, unpublished data). However, the water holding capacity of most of the tanks has been reduced significantly due to aquatic weeds, eutrophication and heavy siltation. Hence, most of the tanks are facilitating only for Maha season and lack of irrigation water has become a problem in the Yala season (Gunarathna \& Kumari, 2014).

Anthropogenic activities cause stresses on Malwathu Oya by impairing the quality of its water (Perera et al., 2014). With respect to irrigation-related water quality of the reservoirs, Nachchaduwa has exceeded the threshold value of electrical conductivity $\left(0.750 \mathrm{mScm}^{-1}\right)$ and salinity (0.500 $\left.\mathrm{gL}^{-1}\right)$ (Silva, 2004). Water of the nearby paddy lands is diverted to the river from different locations during cultivation seasons (Perera et al., 2014). The stream has been (mis) used as a site for waste disposal in the urban area and water becomes polluted easily (De Alwis, 2006).

Significantly higher concentrations of $\mathrm{NO}_{3}^{-}, \mathrm{PO}_{4}^{3-}$ and $\mathrm{Cl}^{-}$in streams during the first inter-monsoon season (March-April) in the paddy growing areas have been observed, along with the highest mean dissolved oxygen (DO) and turbidity values observed in the northeast monsoon season (December-February) in Malwathu Oya. The chemical fertiliser application with the paddy cultivation is contributing to the statistically significant seasonal variations observed in the water quality parameters (Perera et al., 2014). In addition the outlet of the main stream from the Anuradhapura city and the canal flowing across the city, have shown higher values for total dissolved solids, $\mathrm{pH}$, electrical conductivity, DO level, $\mathrm{NO}_{3}^{-}$, and $\mathrm{PO}_{4}^{3-}$, confirming the impact of urban land use on water pollution in Malwathu Oya (Madushanka et al., 2015). In addition, the fate and behaviour of excess $\mathrm{N}$ and $\mathrm{P}$ added to the waterways as fertilisers applied in paddy lands and other crop areas in the upstream catchment areas remain unresolved, and suspected to be a cause of the high prevalence of chronic kidney disease of unknown aetiology $(\mathrm{CKDu})$ in the area (Munasinghe et al., 2015).

Therefore, water resources management alternatives (to overcome issues occurring due to water scarcity, climate change impact, etc.) and measures to address issues related to degrading water quality (caused due to excessive use of fertilisers and agro-chemicals etc.) in the basin should be studied, while the fate of pollutants including their conveyance and spatial and temporal accumulation patterns should also be investigated by studying the dispersal and accumulation behaviour of these elements after they have been added to the crop fields and waterways.

Physics-based distributed hydrological models can take account of temporal and spatial variations of all variables and parameters involved in the basic mathematical equations of the water flows for a watershed. In addition, the used parameters are physically measurable. Therefore, they give a detailed and potentially more correct description of the hydrological processes in the watershed than empirical and conceptual hydrological models. Today, there exist several popular models of this type, like SHE, IHDM, SWAT, MIKE SHE (Jia et al., 2001a) and WEP (Water and Energy transfer Processes) model (Jia et al., 2001b). 
The WEP model has been developed by adding more detailed energy balance analysis in hydrological modelling (Jia \& Tamai, 1998). Its main differences from other physics-based models involve detailed consideration of energy transfer processes, use of sub- grid heterogeneity of land use, application of generalised Green-Ampt model to save computation time and its potential use for various scenario analyses. It has been further improved by coupling a soil erosion-transport model to introduce a particle-bound pollutant component (Rajapakse et al., 2010), and by adding simulation of multi-layered aquifers, direct computation of groundwater outflow to rivers and simulation of infiltration trenches. It has been successfully applied to river basins in Japan, Korea and China (Jia et al., 2001a; 2001b; 2007; Rajapakse et al., 2010; Cunwen et al., 2011). Detailed descriptions of model development, hydrologic and material transport modelling procedures and input/output data, are given in the literature [Jia et al. (2001a; 2001b; 2005) and Rajapakse et al. (2010)].

Therefore, the present study incorporated the WEP model to the Nachchaduwa sub-catchment to assess the current status of the basin concerning the water resources management and pollute transport.

\section{METHODOLOGY}

\section{Study area}

Nachchaduwa catchment was selected as the study area since it is the uppermost sub-catchment in the Malwathu Oya basin, therefore no effect from upstream catchments have to be considered. Further, because of the location of a major reservoir, the reservoir effect could also be modelled.

Nachchaduwa reservoir is managed by the Department of Irrigation and it is fed by the Malwathu Oya and the feeder canal from Kala wewa. It has an irrigable area of 2833 ha and a catchment area of $598.74 \mathrm{~km}^{2}$.

Nachchaduwa catchment consists of several land use types, which include chena, forests, home gardens/ gardens, other cultivations, paddy, rock, scrub land, as well as water bodies. According to the digital maps prepared by the Survey Department of Sri Lanka in year 2001 , the soil types of the catchment are mainly composed of alluvial soils of variable texture and drainage (in flat terrain) in the vicinity of the stream paths and reddishbrown earths and low humic gley soils everywhere else.
The entire catchment has been delineated into three sub-catchments according to the terrain and stream path distribution (Figure 1).

\section{Collection and pre-processing of data}

The model input data required for the hydrological component and the material transport component were collected and processed. Streamflow related data and Nachchaduwa reservoir operation data (sluice release, spill release, water issues, irrigation issues, etc.) were collected from the Department of Irrigation. Land use details and soil types of the catchment were extracted from the spatial maps prepared by the Survey Department in year 2001. Geological and soil layer details were obtained from the borehole data of the construction projects undertaken in the close proximity.

Meteorological data including rainfall, temperature, wind velocity, relative humidity and sunshine hours were collected from the Meteorological Department and checked using the hydrological and statistical data checking procedures. Daily rainfall data for the stations, Anuradhapura, Kahatagasdigiliya, Kekirawa, Maha Illuppallama, and Pelwehera were collected and the Thiessen average daily rainfall values were calculated.

The WEP model has the capacity to simulate hourly data. Since hourly data were not available, it was checked whether an improvement could be made by using hourly data generated from daily data, following the Disaggregated Rainfall Method (Bennett et al., 2015). Excel Visual Basic for Applications (VBA) was used for data pre-processing and to prepare the input files necessary for the model runs. For calibration, data from year 2008 to 2011 and for validation, data from year 2012 to 2015 , were used.

\section{Development of streamflow data series}

The streamflow and reservoir operation data were checked against the rainfall values to identify the catchment response and impact of reservoir storage. The monthly and annual runoff coefficients were calculated and the response of the catchment (total outflow from the reservoir) with precipitation was checked. It was noted that during certain years, the rainfall and total outflow from the reservoir do not show a good correlation due to lack of reliable reservoir operation related data. The catchment response to the rainfall indicated that the measured spill and total release data are highly regulated due to reservoir storage effect (ungauged basin and 
regulated flows). Due to these reasons, a previously calibrated HEC-HMS [Hydrologic Engineering Centre's Hydrologic Modelling System, developed by the United States Army Corps of Engineers (USACE)] model that was developed for this catchment was applied in the present study by incorporating the most suitable parameter values taken from previously published studies (loss method - soil moisture accounting, transform method - Clark unit hydrograph method, baseflow method - constant monthly method) (Hettiarachchi, 2008; Kamran \& Rajapakse, 2017). The outflow values from the total basin were obtained for a $1 \mathrm{~h}$ time interval from the HEC-HMS model and used as the streamflow data series for comparison with the WEP model.

\section{Water balance and yield analysis}

A situation analysis was carried out by conducting a yield analysis to verify the current water scarce situation in the Nachchaduwa sub-catchment. Irrigation requirement was calculated considering the current practice in the scheme; low land paddy (135 days) for the Maha season and low land paddy (105 days) and other field crops (OFC) for the Yala season. Subsequently, a water balance study was carried out considering $75 \%$ probability rainfall values (Ponrajah, 1984), which were the design rainfall values for the reservoir operation study, and the Thiessen average daily rainfall values of collected data. The reservoir operation study model outputs were compared with actual operational data of the Nachchaduwa reservoir for verification. Thereafter, an alternative cropping option was considered by using low land paddy (105 days) for Maha season and low land paddy (105 days) and OFC for the Yala season, to determine whether an improvement is achievable for the water resources management.

\section{Water quality testing}

$\mathrm{N}$ and $\mathrm{P}$ can be found in several different forms in water, mainly in dissolved and particulate forms (Hydrologic Engineering Research Team, 2012). Water quality samples were collected throughout the stream cascade covering both dry and wet seasons and they were tested for the water quality parameters (i.e. $\mathrm{N}$ and $\mathrm{P}$ ), total suspended solids (TSS), turbidity, temperature and $\mathrm{pH}$ value, following American Public Health Association (APHA) (2005). Four $500 \mathrm{~mL}$ samples per one location were collected from eight locations throughout the catchment considering reservoirs, stream segments, inlets and outlets of streams from paddy fields, etc. Half of the samples were preserved by adding $0.5 \mathrm{~mL}$ of concentrated sulfuric $\left(\mathrm{H}_{2} \mathrm{SO}_{4}\right)$ acid. One unfiltered and another filtered (using $0.45 \mu \mathrm{m}$ syringe filters) sample each, were collected from all the locations. The samples were tested for $\mathrm{N}$ and $\mathrm{P}$ using the persulfate method for simultaneous determination of total nitrogen and total phosphorus (APHA, 2005). The samples were checked for the concentrations of anions (such as $\mathrm{NO}_{3}^{-}, \mathrm{NO}_{2}^{-}$and $\mathrm{PO}_{4}^{3-}$ ) in ppm by using the 930 Compact IC Flex Ion Chromatography system (Metrohm AG, Switzerland). For checking the $\mathrm{NH}_{4}^{+}-\mathrm{N}$, the UDK 149 Automatic Kjeldahl Distillation Unit (VELP Scientifica Srl, Italy) was used.

The previous test results were confirmed by conducting colourimetric testing using the Palintest Photometer (Palintest Ltd., England). For determining $\mathrm{PO}_{4}^{3-}, \mathrm{NO}_{2}^{-}$and $\mathrm{NO}_{3}^{-}$, the Palintest Phosphate, Palintest Nitrocol and the Palintest Nitratest methods were used. The colourimeter was used for determining $\mathrm{NH}_{4}^{+}$by Nessler's method.

\section{Fertiliser input data}

Fertiliser issuance data for urea $\left[\mathrm{CO}\left(\mathrm{NH}_{2}\right)_{2}\right]$, triple super phosphate (TSP) $\left[\mathrm{Ca}\left(\mathrm{H}_{2} \mathrm{PO}_{4}\right)_{2} \cdot \mathrm{H}_{2} \mathrm{O}\right]$ and muriate of potash (MOP) $(\mathrm{KCl})$ fertilisers, from 2011 Yala season to $2015 / 2016$ Maha season in the entire Anuradhapura District were collected from the Anuradhapura Divisional Secretariat Division Office. The Divisional Secretariat Divisions (DSD) and their related Agrarian Service Centres (ASC), their total area, the area inside the catchment, paddy, other crops and homestead areas, required as model inputs were calculated from the spatial maps.

All the fertiliser issued by the Anuradhapura DSD were assumed to be applied for paddy. Missing data were filled by the seasonal average values (average of Yala and Maha seasons from 2011 to 2016), and the dataset was developed from 2008 Yala to 2016 Yala season. Urea is composed of $46 \%$ nitrogen and TSP is composed of $45 \%$ phosphorus. It was assumed that $30 \%$ and $10 \%$ of the fertiliser amount applied for paddy is equal to the fertiliser amounts applied for other crops and homesteads, respectively. The $\mathrm{N}$ and $\mathrm{P}$ amounts applied $(\mathrm{kg} / \mathrm{ha})$ every month for all the crops were calculated, according to the application patterns of fertilisers relevant to the current practices in the catchment. The applied amounts were compared with the required amounts of fertilisers, which were found in literature (Table 1).

\section{Preparation of model data input files}

A total of 43 hydrological component input files and 14 material transport component input files is necessary for the WEP model run. The Digital Elevation Model (DEM) 
Table 1: Required amounts of fertilisers for crops

\begin{tabular}{|c|c|c|c|c|c|}
\hline Crop type & Growth stage & Required amount & Yala & Maha & Reference/remarks \\
\hline \multirow{3}{*}{ Paddy } & $\begin{array}{l}\text { Day of transplanting } \\
\text { (basal application) }\end{array}$ & $40 \mathrm{~kg} / \mathrm{ha}$ phosphorus & April & October & \multirow{3}{*}{$\begin{array}{l}\text { United States Peace } \\
\text { Corps (1980) }\end{array}$} \\
\hline & $\begin{array}{l}\text { Active tillering } \\
\text { (first top dressing) }\end{array}$ & $\begin{array}{l}20 \mathrm{~kg} / \mathrm{ha} \text { nitrogen } \\
20 \mathrm{~kg} / \text { ha potassium }\end{array}$ & May, June & $\begin{array}{l}\text { November, } \\
\text { December }\end{array}$ & \\
\hline & $\begin{array}{l}\text { Panicle initiation } \\
\text { (second top dressing) }\end{array}$ & $\begin{array}{l}20 \mathrm{~kg} / \text { ha nitrogen } \\
20 \mathrm{~kg} / \text { ha potassium }\end{array}$ & $\begin{array}{l}\text { July, August, } \\
\text { September }\end{array}$ & $\begin{array}{l}\text { January, February, } \\
\text { March }\end{array}$ & \\
\hline \multirow{3}{*}{ Other crops } & $\begin{array}{l}\text { Basal dressing } \\
\text { (before sowing) }\end{array}$ & $\begin{array}{l}16.1 \mathrm{~kg} / \mathrm{ha} \text { nitrogen } \\
45 \mathrm{~kg} / \mathrm{ha} \text { phosphorus }\end{array}$ & April & October & \multirow{3}{*}{$\begin{array}{l}\text { Mung beans (Field } \\
\text { Crops Research and } \\
\text { Development Institute, } \\
\text { n.d.) }\end{array}$} \\
\hline & $\begin{array}{l}\text { Top dressing } \\
\text { (at flowering) }\end{array}$ & $13.8 \mathrm{~kg} / \mathrm{ha}$ nitrogen & May, June & $\begin{array}{l}\text { November, } \\
\text { December }\end{array}$ & \\
\hline & No fertiliser required & & $\begin{array}{l}\text { July, August, } \\
\text { September }\end{array}$ & $\begin{array}{l}\text { January, February, } \\
\text { March }\end{array}$ & \\
\hline \multirow{3}{*}{ Homesteads } & $\begin{array}{l}\text { Basal dressing } \\
\text { (before sowing) }\end{array}$ & $\begin{array}{l}3.22 \mathrm{~kg} / \mathrm{ha} \text { nitrogen } \\
9 \mathrm{~kg} / \mathrm{ha} \text { phosphorus }\end{array}$ & April & October & \multirow{3}{*}{$\begin{array}{l}\text { Assumption: one fifth } \\
\text { of the required amount } \\
\text { for other crops (Field } \\
\text { Crops Research and } \\
\text { Development Institute, } \\
\text { n.d.) }\end{array}$} \\
\hline & $\begin{array}{l}\text { Top dressing } \\
\text { (at flowering) }\end{array}$ & $2.76 \mathrm{~kg} / \mathrm{ha}$ nitrogen & May, June & $\begin{array}{l}\text { November, } \\
\text { December }\end{array}$ & \\
\hline & No fertiliser required & & $\begin{array}{l}\text { July, August, } \\
\text { September }\end{array}$ & $\begin{array}{l}\text { January, February, } \\
\text { March }\end{array}$ & \\
\hline
\end{tabular}

obtained by the Survey Department had a resolution of $90 \mathrm{~m}$. It was reclassified using ArcGIS to obtain a 300 $\mathrm{m} \times 300 \mathrm{~m}$ resolution grid for the catchment. The input files containing the elevation, slope, flow direction and flow accumulation of each grid cell were developed by using ArcGIS and Excel VBA macros. The stream was divided into 13 channel sections. For this study, 9 soil layers; interception layer, depression layer, three upper soil layers (thickness $0.2 \mathrm{~m}, 0.4 \mathrm{~m}, 1.4 \mathrm{~m}$ ), transition layer $(0.5 \mathrm{~m})$, unconfined aquifer $(12 \mathrm{~m})$, aquitard 1 (12 $\mathrm{m})$, confined aquifer $1(12 \mathrm{~m})$, aquitard $2(12 \mathrm{~m})$, and confined aquifer $2(12 \mathrm{~m})$ were considered based on the actual formation of strata in the soil. The thickness of each layer and initial moisture content of each surface soil layer (3 layers) in each grid, were given as related input files. The Grama Niladari Division (GND)-wise population and water supply data for the year 2012 were found from the statistical reports published (Department of Census and Statistics-Sri Lanka, 2012). The population density and the well density related to each cell were computed to prepare relevant input files.

Further, input files for the material transport component were prepared using the previously calculated fertiliser data for all crops, considering $\mathrm{N}$ and $\mathrm{P}$. It was assumed that the total amount of nutrients a plant would absorb $(\mathrm{kg})$ is equal to the required amount to the plant. The amount of $\mathrm{N}$ was presumed as the summation of the amount added by fertiliser and the amount produced in farmlands from $\mathrm{N}$ fixation [by lightening (Miyamoto et al., 2008), combustion (Deacon, n.d.), and plant $\mathrm{N}$ fixation (Cash et al., 1981; Walley et al., 1996)]. Denitrification was analysed by the model itself. Further details of the modelling approach of the non-point and point sources of pollution are given in Rajapakse et al. (2010).

Apart from these, input files related to the controlling parameters, sub-catchment delineation, land use, meteorological data, soil parameters, river channel element details, aquifer details, initial groundwater levels, etc. have also been prepared for the model runs.

\section{Parameter sensitivity analysis}

The sensitivity of the WEP model results to all the parameters governing the water quality was identified by varying the parameter values within a pre-determined range $( \pm 25 \%)$ and comparing the WEP model results with the previously published water quality data in the same basin. 


\section{RESULTS AND DISCUSSION}

\section{Rainfall - streamflow analysis}

Figure 2 represents the variation of the catchment response (total daily outflow from the reservoir calculated from the collected reservoir operation data) with the
Thiessen average rainfall, confirming the catchment characteristic of having highly regulated flows owing to the storage effect of the plethora of reservoirs in the catchment. Further, the time of concentration for the catchment was found to be 25.8 hours following Ponrajah (1984). The annual runoff coefficient varied from 0.15 to 0.27 within the study period.

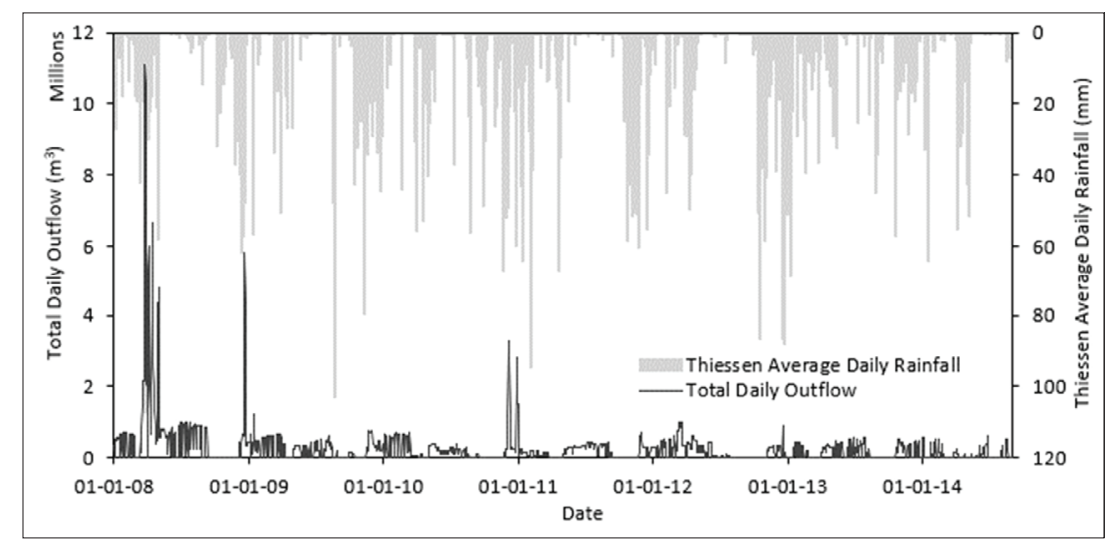

Figure 2: Thiessen average daily rainfall and total daily outflow from the reservoir

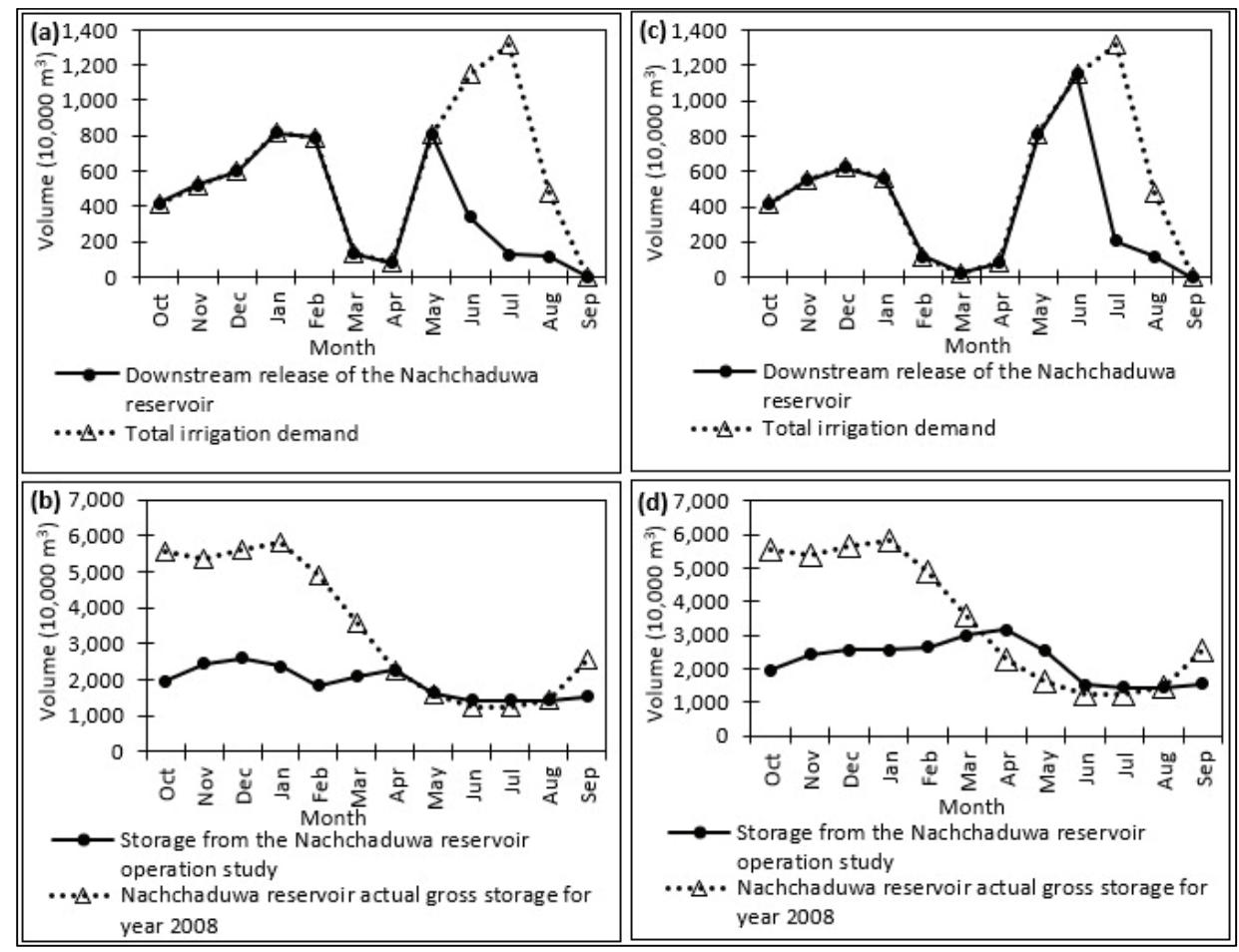

Figure 3: Results of the yield analysis; (a) annual demand and supply - current situation; (b) verification of the reservoir operation study model outputs with the actual operational data - current situation; (c) annual demand and supply - alternative cropping pattern; (d) verification of the reservoir operation study model outputs with the actual operational data - alternative cropping pattern 
Water balance/yield analysis in Nachchaduwa subcatchment

The results of yield analyses are presented in Figure 3. Yield analysis confirmed that there is water scarcity in the catchment, especially during the dry season extending from April to September. As seen from Figure 3(c), the gap between the demand and supply of water has been reduced with the alternative cropping option, confirming that an improvement is achievable for the water resources management. However, even with the alternative cropping option, still there is water scarcity prevalent in the catchment.

\section{Reservoir and streamflow water quality analysis}

According to the water quality test results of the samples that were collected throughout the stream cascade in the dry season (Yala season), the single factor ANOVA test $\mathrm{P}$ values for the upstream and downstream concentrations of $\mathrm{NH}_{4}^{+}-\mathrm{N}$ and $\mathrm{PO}_{4}^{3-}-\mathrm{P}$ are, 0.166 and 0.792 , respectively. The $\mathrm{NO}_{3}^{-}-\mathrm{N}$ and $\mathrm{NO}_{2}^{-}-\mathrm{N}$ concentrations were below the minimum measurable limit of the apparatus.

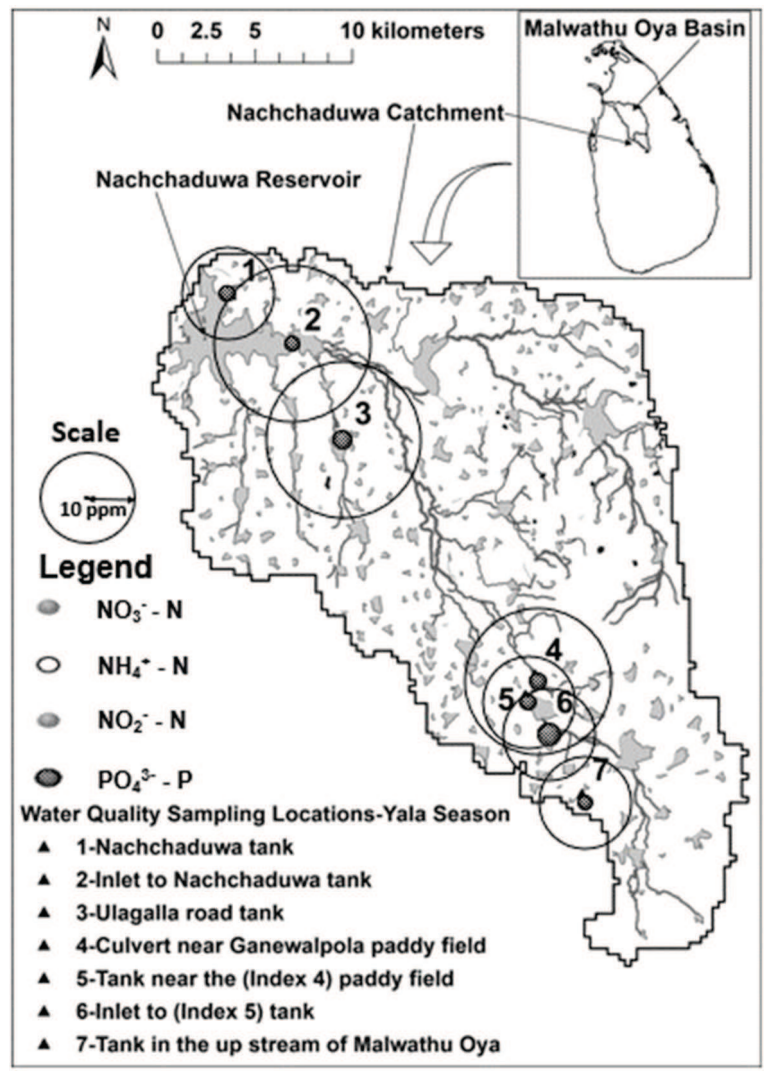

Figure 4: Water quality test results with the sampling locations Yala season (nitrogen and phosphorus components)
According to the water quality test results of the samples that were collected throughout the stream cascade in the wet season (Maha season), the single factor ANOVA test $\mathrm{P}$ values for the upstream and downstream concentrations of total nitrogen (TN), dissolved nitrogen $(\mathrm{DN})$, particulate nitrogen $(\mathrm{PN})$, total phosphorus (TP), dissolved phosphorus (DP) and particulate phosphorus (PP) are, 0.306, 0.204, 0.480, 0.170, 0.383, 0.307, respectively.

Therefore, in both seasons, the differences between the upstream and downstream concentration values of the water quality parameters are not statistically significant, despite the slightly increasing or decreasing trends shown from upstream to downstream sites, as graphically illustrated by the bubble diagrams in Figures 4 and 5.

However, according to Figures 4 and 5, most of the nutrient concentrations (TN, DN, TP, PP) tend to increase towards the downstream of the catchment (although those variations are not statistically significant) presumably due to the accumulation of nutrients in the streams, but the concentrations measured in the Nachchaduwa reservoir has shown lower values owing to the dilution effect.

\section{Fertiliser input and dispersal analysis}

For paddy, other crops and homesteads, the monthly average values of applied $\mathrm{N}$ and $\mathrm{P}$ amounts $(\mathrm{kg} / \mathrm{ha})$ of each month have been calculated (considering the data for years 2008 Yala to 2016 Yala) and compared with the $\mathrm{N}$ and $\mathrm{P}$ amounts required by the crop. It was noted that in this sub-catchment, the applied $\mathrm{N}$ and $\mathrm{P}$ amounts $(\mathrm{kg} / \mathrm{ha})$ in almost all months for all three types of crops that were considered have exceeded the plant required amounts.

The input fertiliser amounts and the uptake fertiliser amounts from the crops were calculated and the variation of total input and total uptake (from the crops) of $\mathrm{N}$ in each year (for the years 2008-2011 are shown), in each ASC are shown in Table 2 and the same for $\mathrm{P}$ are shown in Table 3.

\section{WEP model results}

The WEP model is capable of providing time series values of water and heat balance as well as water quality and material transport results for each grid, as outputs. The preliminary results pertaining to the hydrological and material transport processes have been presented in this paper. 


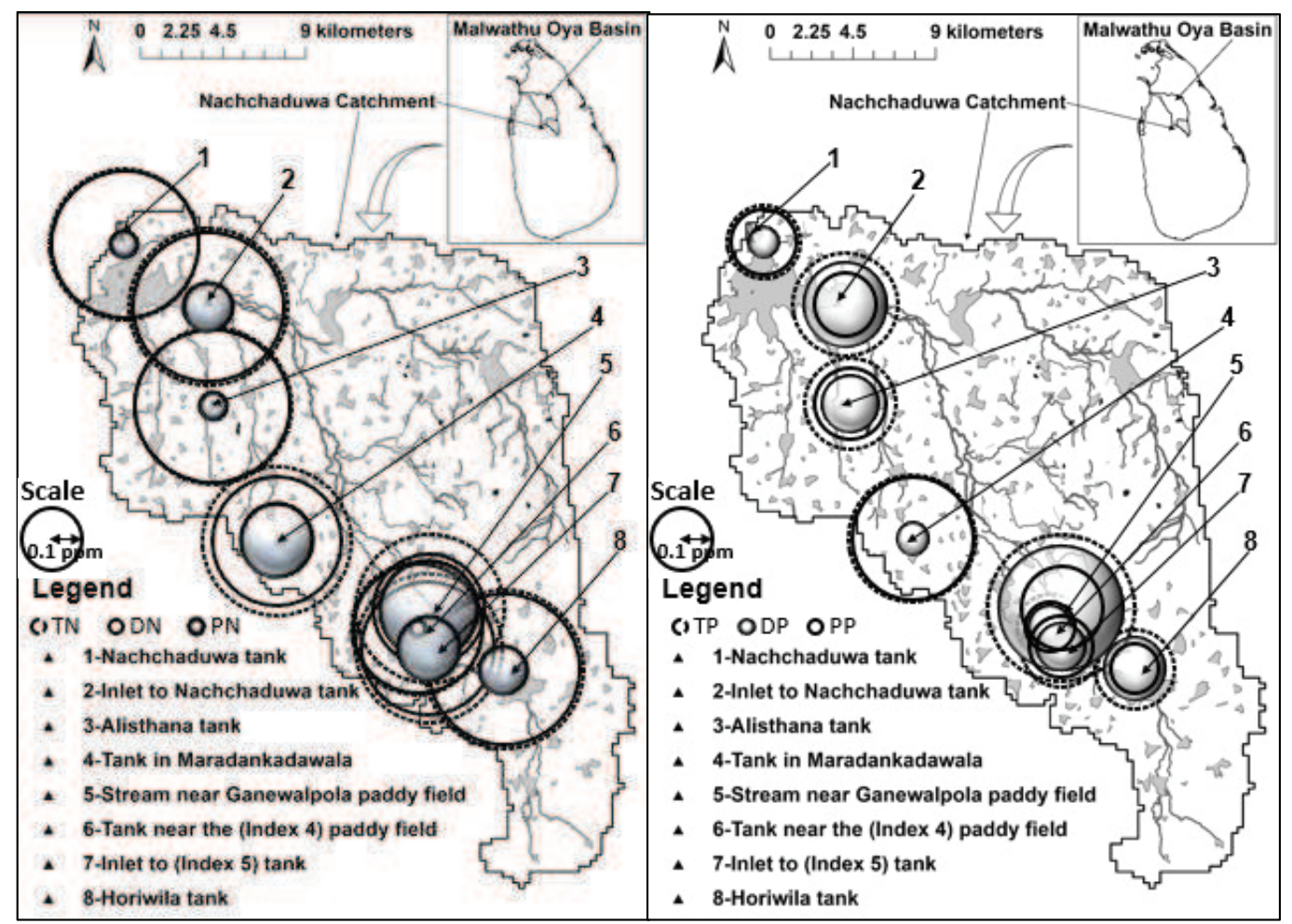

Figure 5: Water quality test results with the sampling locations - Maha season (nitrogen and phosphorus components)

Table 2: Variation of total input and total uptake of nitrogen $(\mathrm{kg})$ each year in each Agrarian Service Centre (ASC)

\begin{tabular}{lllllllll}
\hline \multirow{2}{*}{ ASC } & \multicolumn{4}{c}{ Total N input $(\mathrm{kg})$} \\
\cline { 2 - 9 } & 2008 & 2009 & 2010 & 2011 & 2008 & 2009 & 2010 & 2011 \\
\hline Siwalakulama & 324,040 & 324,040 & 324,040 & 366,344 & 301,466 & 301,466 & 301,466 & 301,466 \\
Yakalla & 50,025 & 50,025 & 50,025 & 66,335 & 21,817 & 21,817 & 21,817 & 21,817 \\
Galenbindunuwewa & 23,097 & 23,097 & 23,097 & 30,503 & 7,606 & 7,606 & 7,606 & 7,606 \\
Ipalogama & 96,114 & 96,114 & 96,114 & 118,686 & 20,150 & 20,150 & 20,150 & 20,150 \\
Kekirawa & 160,630 & 160,630 & 160,630 & 206,742 & 86,425 & 86,425 & 86,425 & 86,425 \\
Maradankadawala & 341,351 & 341,351 & 341,351 & 423,338 & 273,000 & 273,000 & 273,000 & 273,000 \\
Madatugama & 255,009 & 255,009 & 255,009 & 322,782 & 116,014 & 116,014 & 116,014 & 116,014 \\
Mihintale & 839 & 839 & 839 & 1,254 & 0 & 0 & 0 & 0 \\
Shrawasthipura & 162,474 & 162,474 & 162,474 & 216,407 & 31,487 & 31,487 & 31,487 & 31,487 \\
Anuradhapura & 12,627 & 12,627 & 12,627 & 16,760 & 6,713 & 6,713 & 6,713 & 6,713 \\
Palugaswewa & 399,714 & 399,714 & 399,714 & 465,819 & 246,264 & 246,264 & 246,264 & 246,264 \\
Thirappane & 629,629 & 629,629 & 629,629 & 835,730 & 472,092 & 472,092 & 472,092 & 472,092 \\
Muriyakadawala & 346,154 & 346,154 & 346,154 & 485,063 & 273,713 & 273,713 & 273,713 & 273,713 \\
Kibissa & 122,280 & 122,280 & 122,280 & 128,724 & 36,038 & 36,038 & 36,038 & 36,038 \\
\hline Total & $2,923,983$ & $2,923,983$ & $2,923,983$ & $3,684,488$ & $1,892,784$ & $1,892,784$ & $1,892,784$ & $1,892,784$ \\
\hline
\end{tabular}


Table 3: Variation of total input and total uptake of phosphorus $(\mathrm{kg})$ each year in each Agrarian Service Centre (ASC)

\begin{tabular}{lllllllll}
\hline \multirow{2}{*}{ ASC } & \multicolumn{4}{c}{ Total P input $(\mathrm{kg})$} & \multicolumn{5}{c}{ Total P output (plant uptake) (kg) } \\
\cline { 2 - 9 } & 2008 & 2009 & 2010 & 2011 & 2008 & 2009 & 2010 & 2011 \\
\hline Siwalakulama & 79,099 & 79,099 & 79,099 & 118,254 & 126,819 & 126,819 & 126,819 & 126,819 \\
Yakalla & 12,110 & 12,110 & 12,110 & 18,572 & 9,472 & 9,472 & 9,472 & 9,472 \\
Galenbindunuwewa & 6,010 & 6,010 & 6,010 & 8,929 & 3,260 & 3,260 & 3,260 & 3,260 \\
Ipalogama & 20,115 & 20,115 & 20,115 & 29,349 & 12,404 & 12,404 & 12,404 & 12,404 \\
Kekirawa & 37,879 & 37,879 & 37,879 & 57,287 & 37,183 & 37,183 & 37,183 & 37,183 \\
Maradankadawala & 75,015 & 75,015 & 75,015 & 112,156 & 116,839 & 116,839 & 116,839 & 116,839 \\
Madatugama & 61,150 & 61,150 & 61,150 & 88,319 & 49,552 & 49,552 & 49,552 & 49,552 \\
Mihintale & 242 & 242 & 242 & 393 & 0 & 0 & 0 & 0 \\
Shrawasthipura & 42,663 & 42,663 & 42,663 & 65,104 & 13,438 & 13,438 & 13,438 & 13,438 \\
Anuradhapura & 1,719 & 1,719 & 1,719 & 3,129 & 3,498 & 3,498 & 3,498 & 3,498 \\
Palugaswewa & 56,315 & 56,315 & 56,315 & 84,219 & 130,187 & 130,187 & 130,187 & 130,187 \\
Thirappane & 116,874 & 116,874 & 116,874 & 202,774 & 216,837 & 216,837 & 216,837 & 216,837 \\
Muriyakadawala & 75,907 & 75,907 & 75,907 & 128,533 & 117,035 & 117,035 & 117,035 & 117,035 \\
Kibissa & 5,490 & 5,490 & 5,490 & 8,210 & 32,809 & 32,809 & 32,809 & 32,809 \\
\hline Total & 590,586 & 590,586 & 590,586 & 925,228 & 869,332 & 869,332 & 869,332 & 869,332 \\
\hline
\end{tabular}

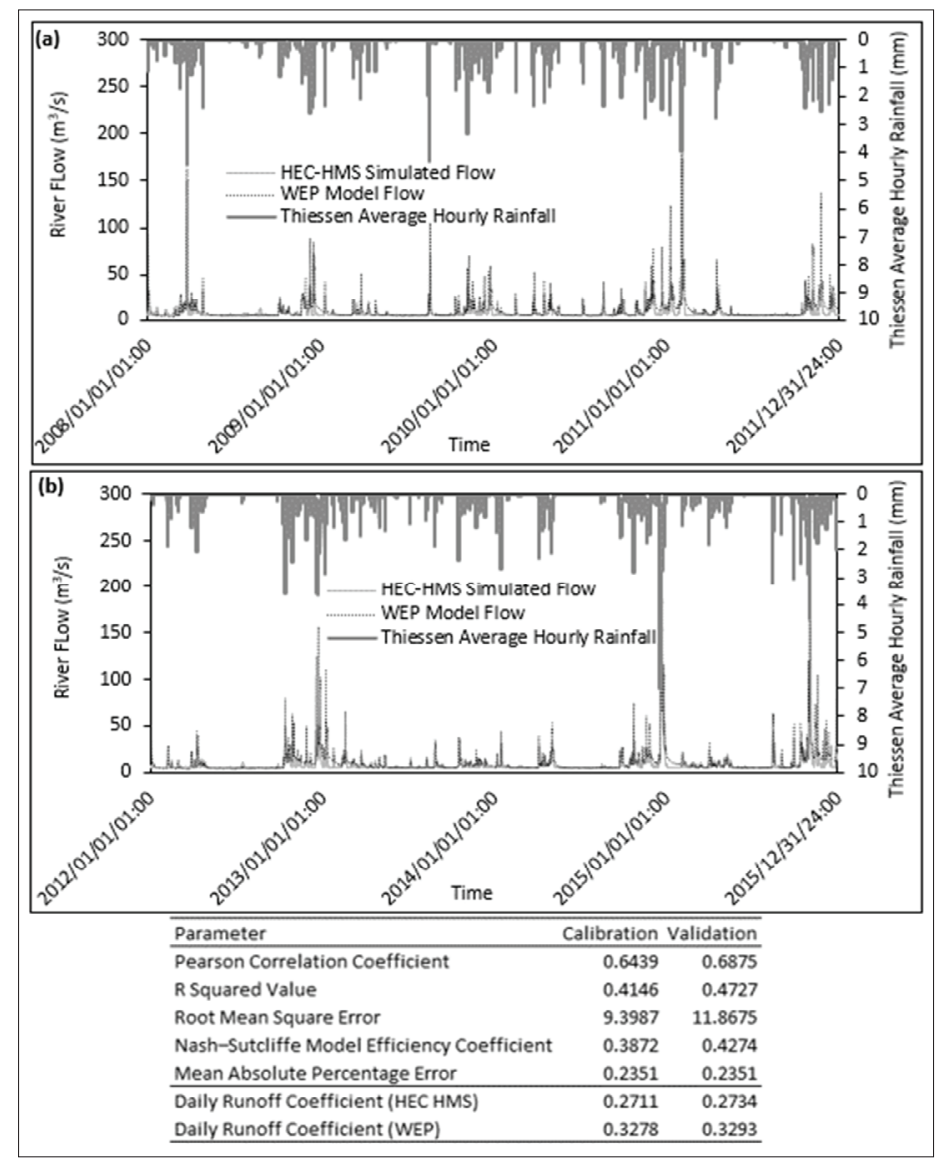

Figure 6: WEP model streamflow comparison with HEC-HMS model results; (a) calibration period, (b) validation period 


\section{Streamflow comparison with HEC-HMS model results}

The WEP model generated streamflow values for both calibration and validation periods have been compared with the streamflow time series obtained based on the pre-calibrated HEC-HMS model. The WEP model streamflow values are matching with the HEC-HMS model streamflow values (Figure 6), and the validation period showed better results according to the error coefficients (objective functions) used (Pearson correlation coefficient, R squared value, root mean square error, Nash-Sutcliffe model efficiency coefficient and mean absolute percentage error). The values of these error coefficients for both calibration and validation periods are shown in Figure 6. The Pearson correlation coefficient shows a better agreement and the other objective functions used for comparison purposes indicate reduced correlation, presumably due to minor non-stationarities in the data series.
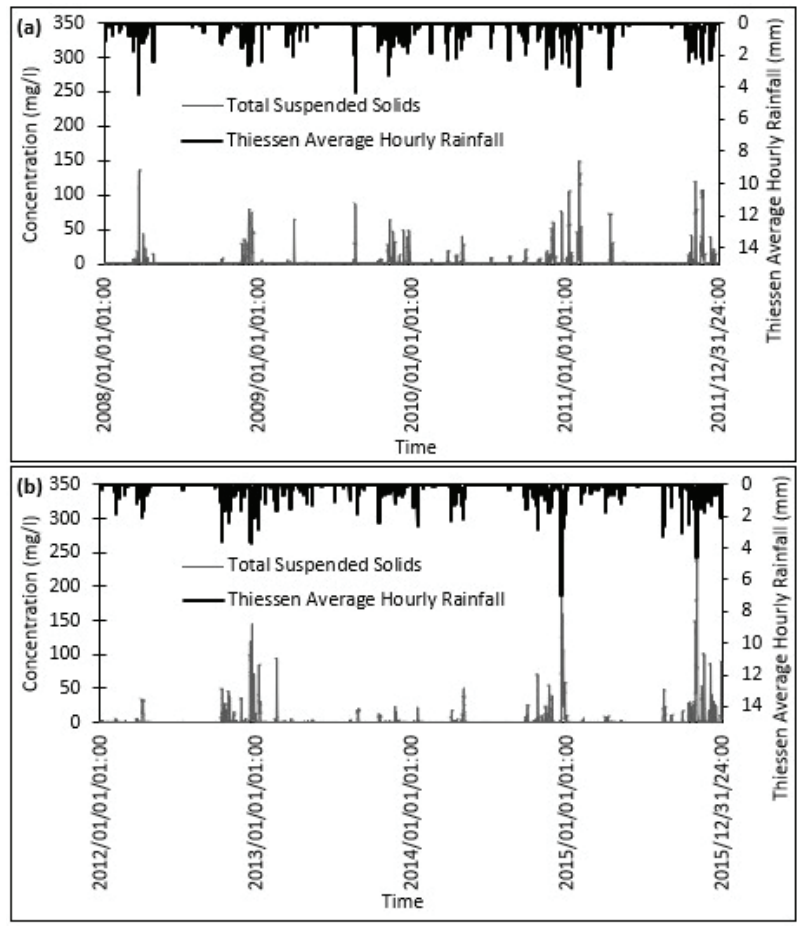

Figure 7: Temporal variation of total suspended solids; (a) calibration period, (b) validation period

\section{Temporal variation of results}

The temporal variation of TSS showed a correlation with the Thiessen average rainfall values, with the peaks and troughs of the TSS graph corresponding to the peaks and troughs of the rainfall graph (Figure 7), implying that the rainfall would induce a washout of the solids, and hence adding them into the streams. The mean \pm standard deviation, minimum and maximum values of TSS were: $0.90 \pm 4.56 \mathrm{mg} / \mathrm{L}, 0.11 \mathrm{mg} / \mathrm{L}$ and $87.40 \mathrm{mg} / \mathrm{L}$ in the calibration dry seasons; $4.79 \pm 14.88 \mathrm{mg} / \mathrm{L}$, $0.13 \mathrm{mg} / \mathrm{L}$ and $148.57 \mathrm{mg} / \mathrm{L}$ in the calibration wet seasons; $0.76 \pm 3.45 \mathrm{mg} / \mathrm{L}, 0.09 \mathrm{mg} / \mathrm{L}$ and $49.94 \mathrm{mg} / \mathrm{L}$ in the validation dry seasons; $5.62 \pm 20.38 \mathrm{mg} / \mathrm{L}$, $0.10 \mathrm{mg} / \mathrm{L}$ and $304.57 \mathrm{mg} / \mathrm{L}$ in the validation wet seasons, respectively. Therefore, on average, the wet season has about five (calibration) to seven (validation) times the dry season value of the TSS in the streams.

Several water quality studies have been conducted focusing on the Nachchaduwa catchment (Wijesundara et al., 2012; 2013; Perera et al., 2014). The temporal variation of WEP model results (TN, DN, PN, TP, DP, PP) were classified under low flow (percentage exceedance flow rate of total river flow less than $10 \%$ ), mid flow (percentage exceedance flow rate of total river flow between $45 \%$ and $55 \%$ ), and high flow (percentage exceedance flow rate of total river flow greater than $90 \%$ ), and have been compared with the findings of the previous studies.

The comparison of WEP model results during the water quality testing period of this study are illustrated in Figure 8. Figure 9 illustrates the comparison of WEP model results for the entire duration of calibration and validation periods, with the entire duration of the three published results.

The three published studies have only measured the water quality as spontaneous measurements, for a shorter duration (only for one-year period), and the water quality parameters under all weather conditions have not been considered (as the sampling has been done once a month in all three studies). But the values of the WEP model results shown are the average of a longer time period (hourly values of all days for a period of four years), and therefore represent a wider and a more reasonable range of values of water quality parameters in the streams. However, it is evident from Figures 8 and 9, that the WEP results are reasonably matching with the published results.

Further, for the $\mathrm{N}$ components for both the calibration period and the validation period, the WEP low flow values showed the best match with the published results. The published values are given for $\mathrm{NO}_{3}^{-}$, therefore, when comparing, the DN component from the WEP results 
should be considered. The DN in the WEP low flow conditions ranges from $0.0023 \mathrm{mg} / \mathrm{L}$ to $3.3177 \mathrm{mg} / \mathrm{L}$ in the calibration period and in the validation period it ranges from $0.00349 \mathrm{mg} / \mathrm{L}$ to $3.6347 \mathrm{mg} / \mathrm{L}$. In the published values, it ranges from $1.05 \mathrm{mg} / \mathrm{L}$ to 12.00 $\mathrm{mg} / \mathrm{L}$ (Perera et al., 2014), hence the WEP results could be justified. In addition, the maximum $\mathrm{NO}_{3}^{-}$concentration in Malwathu Oya river has been found to be $15 \mathrm{mg} / \mathrm{L}$ in the month of August, by Zoysa and Weerasinghe (2016). Therefore, it could be stated that the WEP results are below the maximum value recorded in the basin and below the threshold value of $10 \mathrm{ppm}$ for drinking water (WHO, 2011).

For the $\mathrm{P}$ components, for both the calibration and the validation periods, the WEP high flow values show the best match with the published results. This could be attributed to the fact that, during high flow conditions the high streamflow would induce a washout of the solids, hence most of the particulate nutrients which were adsorbed to the sediments get washed away, adding them to the waterways (Wijesundara et al., 2012). The published values are given for $\mathrm{PO}_{4}^{3-}$, therefore, when comparing, the DP component from the WEP results should be considered. The DP in the WEP high flow conditions ranges from $0.0337 \mathrm{mg} / \mathrm{L}$ to $0.1528 \mathrm{mg} / \mathrm{L}$ in the calibration period, and in the validation period it ranges from $0.03198 \mathrm{mg} / \mathrm{L}$ to $0.1163 \mathrm{mg} / \mathrm{L}$; whereas in the published values it ranges from $0.004 \mathrm{mg} / \mathrm{L}$ to $0.13 \mathrm{mg} / \mathrm{L}$ (Wijesundara et al., 2012), hence the WEP results could be justified. However, these modelled DP values are above the threshold value of $0.08 \mathrm{ppm}$ of $\mathrm{PO}_{4}^{3-}$ for the occurrence of eutrophication (USEPA, 1976). Further, the values of WEP modelled DP were below the threshold of $2 \mathrm{mg} / \mathrm{L}$ of $\mathrm{PO}_{4}^{3-}$ for drinking and irrigation water (WHO, 2011).

The canals and streams of the adjacent Kala Oya river basin have shown $0.0 \mathrm{mg} / \mathrm{L}-10.7 \mathrm{mg} / \mathrm{L}$ and $0.0-23.4 \mathrm{mg} / \mathrm{L}$ of $\left(\mathrm{NO}_{3}^{-}\right)$and $0.02 \mathrm{mg} / \mathrm{L}-2.60 \mathrm{mg} / \mathrm{L}, 0.22-0.66 \mathrm{mg} / \mathrm{L}$ of $\left(\mathrm{PO}_{4}^{3-}\right)$, respectively (Young et al., 2009). Therefore, in both Yala and Maha seasons, the WEP model results of $\mathrm{NO}_{3}^{-}$and $\mathrm{PO}_{4}^{3-}$ are within the ranges of the above published results.
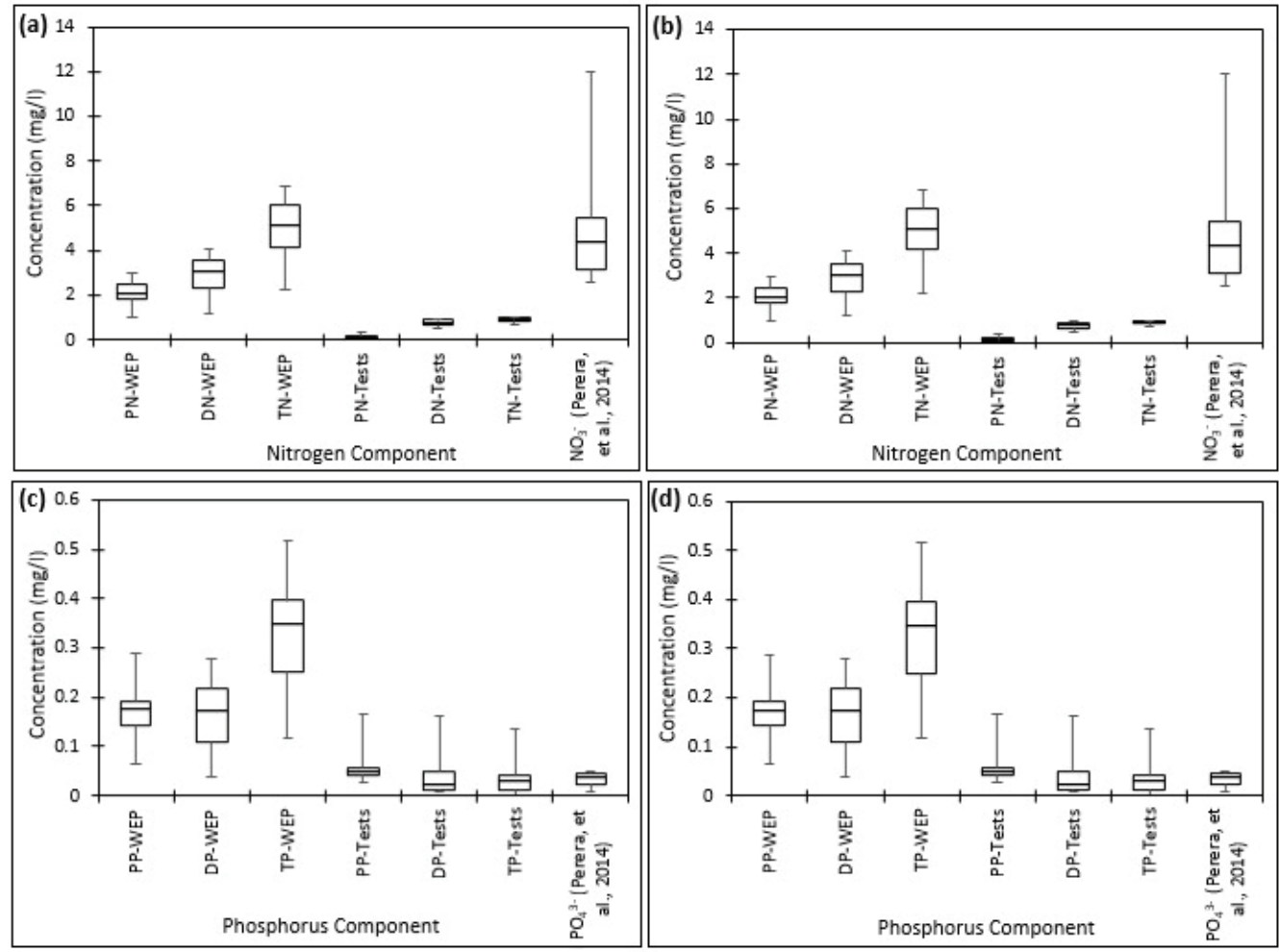

Figure 8: Comparison of WEP results, test results, and published results (PN - particulate nitrogen; DN - dissolved nitrogen; TN - total nitrogen; PP - particulate phosphorus; DP - dissolved phosphorus; TP - total phosphorus). (a) nitrogen components - calibration period; (b) nitrogen components - validation period; (c) phosphorus components - calibration period; (d) phosphorus components - validation period 


\section{Spatial variation of results}

The excess fertiliser dispersal (wash out) paths and accumulation hotspots (the locations with the highest concentration of $\mathrm{N}$ and $\mathrm{P}$ components) of the rivers/land could be identified from the spatial variation results given by the WEP model. These hotspots are the critical areas that would need urgent attention when implementing best management practices for the fertiliser usage. Further, these hotspots could be compared with the $\mathrm{CKDu}$ prone areas in the catchment, to check whether they are spatially correlated.

\section{Sensitivity analysis results}

When comparing the WEP model results with the published water quality results, it has been identified that

$\mathrm{P}$ is the limiting factor. Therefore, the sensitivity of the
WEP model results with all the parameters governing the $\mathrm{P}$ components in all the material transport component input files were analysed. The input files which have the maximum sensitivity to the model results were identified, and all the $\mathrm{P}$ related parameters in those input files were varied by $\pm 25 \%$ to check the model sensitivity.

The parameters governing the $\mathrm{P}$ components in the input file which relates to material movement for the overland flow (surfaceC.csv file) are; decomposition rate from suspended $\mathrm{P}$ to dissolved $\mathrm{P}(\mathrm{RN})$, sedimentation coefficient (KP), amount of the maximum allowable deposit $\left(\mathrm{S}_{\max }\right)$ and amount of initial deposit $\left(\mathrm{S}_{\mathrm{ini}}\right)$. It was found that for DP, only the parameter RN had a significant impact and the other parameters had no significant impact. For $\mathrm{PP}$ and TP, $\mathrm{RN}$ and $\mathrm{S}_{\max }$ had a significant impact, while other parameters had no significant impact.
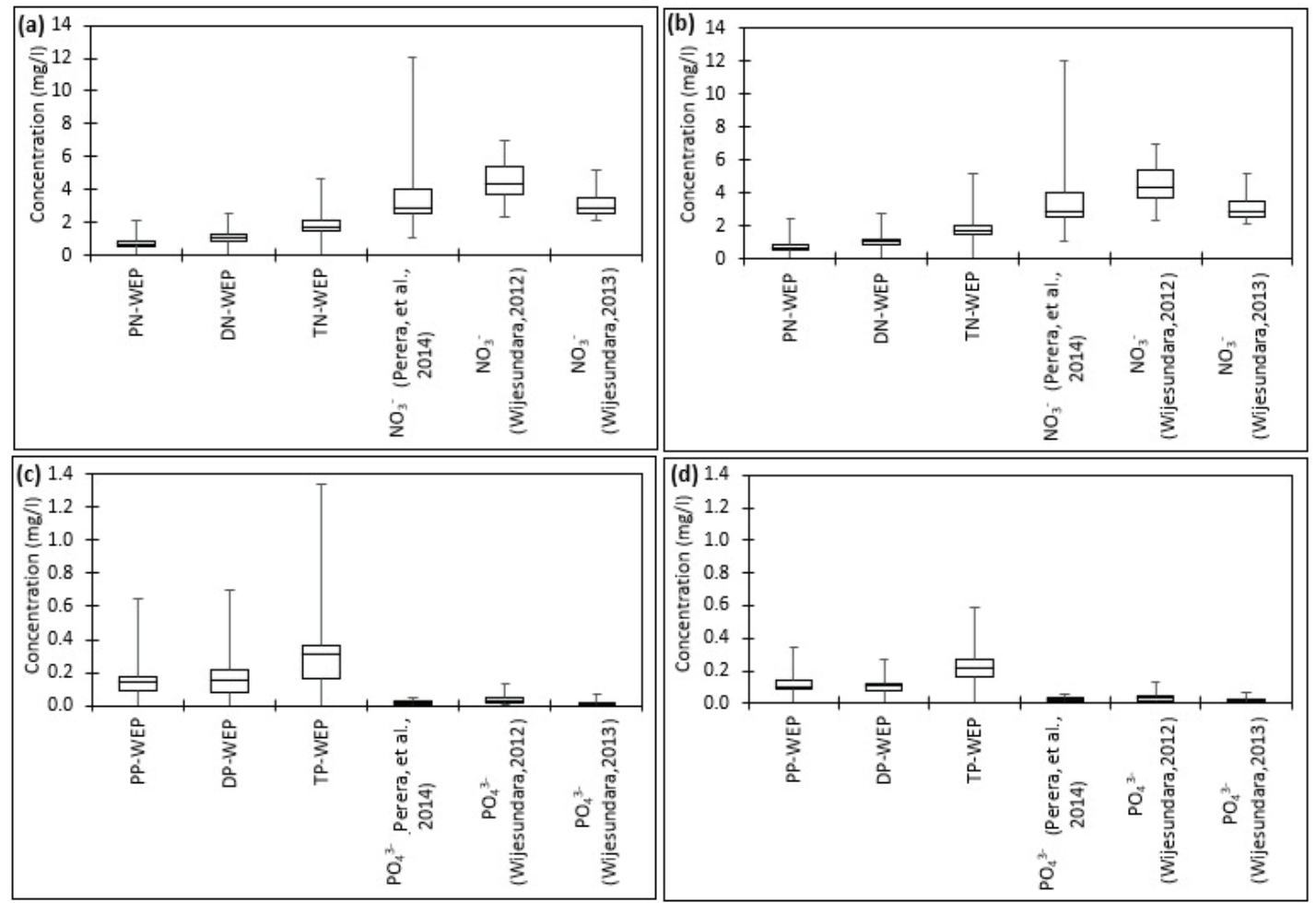

Figure 9: Comparison of WEP results and published results for the entire duration of calibration and validation periods (PN - particulate nitrogen; DN - dissolved nitrogen; TN - total nitrogen; PP - particulate phosphorus; DP - dissolved phosphorus; TP - total phosphorus). (a) nitrogen components - calibration period; (b) nitrogen components validation period; (c) phosphorus components - calibration period; (d) phosphorus components - validation period 
The parameters governing the $\mathrm{P}$ components in the input file which relates to material transport in the river channel (riverC.csv file) are; RN, KP, amount of the maximum allowable riverbed deposit $\left(\mathrm{S}_{\max }\right)$, amount of initial riverbed deposit $\left(\mathrm{S}_{\mathrm{ini}}\right)$, suspended condition phosphorus diffusion coefficient ( $\mu \mathrm{PP})$ and dissolved condition phosphorus diffusion coefficient ( $\mu \mathrm{DP})$. It was found that for DP, none of the parameters has any significant impact. For PP and TP, KP had a significant impact while other parameters had no significant impact.

The parameters governing the $\mathrm{P}$ components in the input file which relates to non-point source material transport in forest and urban area (nonpointsource.csv file) are; DP amount generated by trees in forest and urban areas (aDP) and PP amount generated by trees in forest and urban areas (aPP). It was found that for DP, only aDP has a significant impact. For PP and TP, aDP and aPP have a significant impact.

Sensitivity analysis has shown the response characteristics of the WEP model results to all the parameters governing the $\mathrm{P}$ components in the input files, and it was noted that different parameters have different sensitivity levels to the model results. Although it could be assumed that the pollutant loading due to the point sources in this catchment are less dominant than the non-point sources of pollutants since this catchment is not highly urbanised and developed, the results of the sensitivity analysis have shown that the parameters governing both point sources as well as non-point sources contribute to the variation of WEP model results.

\section{CONCLUSIONS AND RECOMMENDATIONS FOR FUTURE STUDIES}

The present study incorporated a detailed modelling approach to the Nachchaduwa sub-catchment to study the water resources management as well as pollutant transport of the river. Only the present condition has been analysed up to now and this study will be continued in the future to analyse possible hydrological and material transport related scenarios in the catchment. The catchment response to the rainfall indicated that the measured spill and total release data are highly regulated due to reservoir effect, confirming that the catchment needs to be analysed as an ungauged basin with regulated flows, and hence the use of a pre-calibrated HEC-HMS model for verification is justified. Therefore, this research will set the baseline for studying ungauged basins with data scarce situations. The WEP model streamflow values were reasonably matching with the HEC-HMS model streamflow values, and validation period showed better correlation coefficients (Pearson correlation coefficient of 0.6875), establishing the suitability of applying the WEP model for the analysis of water resources in this catchment. Yield analysis confirmed that there is a water scarcity in the catchment, especially during the dry season (April-September), even after implementing the proposed alternative crop pattern. However, an improvement in water resources management is achievable by choosing alternative crop patterns for this catchment.

A distinct variation of the measured dry and wet season water quality parameters was observed in the catchment. For this catchment, the applied $\mathrm{N}$ and $\mathrm{P}$ amounts $(\mathrm{kg} / \mathrm{ha})$ of fertilisers in almost all months for all three types of crops that were considered have exceeded the plant requirement, confirming the necessity of regulation of fertiliser usage. The WEP model results showed that on average, the wet season has about five to seven times the dry season value of the TSS in the streams, establishing that the high washout of nutrients as suspended matter during the high streamflow values in the wet season causes an increase in the concentrations of nutrients in waterways. The water quality values of the WEP model results shown are the average of a longer time period, and therefore represent a wider and a more reasonable range of values of water quality parameters in the streams. Nevertheless, in both Yala and Maha seasons, the WEP model results of $\mathrm{NO}_{3}^{-}$and $\mathrm{PO}_{4}^{3-}$ are within the range of the previously published results.

Sensitivity analysis has shown that the WEP model results have a reasonable response to all the parameters governing the $\mathrm{P}$ components in the input files, and different parameters have different sensitivity levels to the model results. Although it could be assumed that the pollutant loading due to the point sources in this catchment are less significant than the non-point sources of pollutants since this catchment is not a highly urbanised and developed area, the results of the sensitivity analysis have shown that the parameters governing both point sources as well as non-point sources contribute to the variation of WEP model results. More precise and long-term field monitoring and analysis are needed to identify the most critical areas and time periods of the pollutant accumulation, which would be addressed in future studies of this research. This information could be effectively used in decision making with respect to the water resources and pollutant transport management of the catchment. 
The findings of this research will be useful in identifying and for recommending the best management practices and for coping with the excess fertiliser/agrochemical usage of this catchment in a more pragmatic manner. Since the WEP model has been successfully applied in river basins in Japan, Korea and China in similar studies, the results of this study could also be generalised and are applicable to any similar ungauged basin in this region with regulated or unregulated flows.

\section{REFERENCES}

American Public Health Association (APHA) (2005). American Water Works Association \& Water Environment Federation. Standard Methods for the Examination of Water and Wastewater, $21^{\text {st }}$ edition. American Public Health Association, Washington DC, USA.

Bennett J.C., Robertson D.E., Ward P.G.D., Hapuarachchi H.A.P. \& Wang Q.J. (2015). Calibrating hourly rainfallrunoff models with daily forcings for streamflow forecasting applications in meso-scale catchments. Environmental Modelling and Software 76(2016): 20-36.

DOI: https://doi.org/10.1016/j.envsoft.2015.11.006

Cash D., Melton B., Gregory J. \& Cihacek L. (1981). Rhizobium Inoculants for Alfalfa in New Mexico (Research Report 461). New Mexico State University Agricultural Experiment Station, Las Cruces, USA.

Cunwen N., Yangwen J., Hao W., Zuhao Z., Yaqin Q., Shjun B. \& Caixia L. (2011). Assessment of water quality under changing climate conditions in the Haihe River Basin, China. In: Water Quality: Current Trends and Expected Cimate Change Impacts, Proceedings of the Symposium H04 held during IUGG2011 (ed. N.E. Peters), Melbourne, Australia, pp. 165-171.

De Alwis S.M.D.L.K. (2006). Competition for Water Demands, Management Conflicts and Inter-related Issues in Malwathu Oya Basin of Sri Lanka, s.l.: s.n.

Deacon J. (n.d.). The Microbial World: The Nitrogen Cycle and Nitrogen Fixation [Online]. Available at: http://archive. bio.ed.ac.uk/jdeacon/microbes/nitrogen.htm, Accessed 25 February 2017.

Department of Census and Statistics-Sri Lanka (2012). Census of Population and Housing-2012. Department of Census and Statistics-Sri Lanka, Colombo, Sri Lanka.

Field Crops Research and Development Institute (n.d.). Mung Bean [Online]. Available at: https://www.doa.gov.lk/ FCRDI/index.php/si/2015-09-23-04-45-47/35-mung-bean, Accessed 7 February 2017.

Gunarathna M. \& Kumari M. (2014). Sustainable management of Malwathu Oya cascade-I: present status and future needs. GSTF Journal on Agricultural Engineering (JAE) 1(1): 81-85.

Hettiarachchi I. (2008). Modelling runoff characteristics of the Minneriya and Nachchaduwa Catchments. MSc thesis, University of Moratuwa, Moratuwa, Sri Lanka.

Hydrologic Engineering Research Team (2012). WEP Model
Instruction Manual. Hydrologic Engineering Research Team, International Center for Water Hazard and Risk Management, Public Works Research Institute, Ibaraki, Japan.

Jia Y., Ni G., Kawahara Y. \& Suetsugi T. (2001a). Simulation of hydrological cycle in an urbanized watershed and effect evaluation of infiltration facilities with WEP Model. Journal of Hydroscience and Hydraulic Engineering 19(1): 43-52.

Jia Y., Ni G., Kawahara Y. \& Suetsugi T. (2001b). Development of WEP model and its application to an urban watershed. Hydrological Processes 15: 2175-2194.

DOI: https://doi.org/10.1002/hyp.275

Jia Y., Niu C. \& Wang H. (2007). Integrated modeling and assessment of water resources and water environment in the Yellow River Basin. Journal of Hydro-Environment Research 1: 12-19.

DOI: https://doi.org/10.1016/j.jher.2007.04.001

Jia Y. \& Tamai N. (1998). Water and heat balances in the middle-reach catchment of Tama River and sensitivity analysis. Annual Journal of Hydraulic Engineering JSCE 42: 151-156.

DOI: https://doi.org/10.2208/prohe.42.151

Jia Y.W., Kinouchi T. \& Yoshitani J. (2005). Distributed hydrologic modeling in a partially urbanized agricultural watershed using WEP Model. Journal of Hydrologic Engineering 10: 253-263.

Kamran M. \& Rajapakse R.L.H.L. (2017). Effect of watershed subdivisions and antecedent moisture condition on HECHMS model performance in the Maha Oya Basin, Sri Lanka. Proceedings of the $5^{\text {th }}$ International Young Researchers Workshop on River Basin Environment and Management 2017, Kuantan, Malaysia, 28-29 October.

Madushanka R., Dissanayaka D. \& Amarasekara M. (2015). Impact of urban land use in Anuradhapura city on water quality of upper Malwathu Oya stream. Proceedings of the Water Professionals' Day Symposium, s.1., pp. 137-143.

Miyamoto C., Ketterings Q., Cherney J. \& Kilcer T. (2008). Agronomy Fact Sheet Series - Fact Sheet 39 (Online). Available at: http://nmsp.cals.cornell.edu/publications/ factsheets/factsheet39.pdf, Accessed 20 August 2018.

Munasinghe J., De Silva A., Weerasinghe G., Gunaratne A. \& Corke H. (2015). Food safety in Sri Lanka: problems and solutions. Quality Assurance and Safety of Crops and Foods 7(1): 37-44.

DOI: https://doi.org/10.3920/QAS2014.x007

Perera P., Sundarabarathy T., Sivananthawerl T. \& Edirisinghe U. (2014). Seasonal variation of water quality parameters in different geomorphic channels of the upper Malwathu Oya in Anuradhapura, Sri Lanka. Tropical Agricultural Research 25(2): 158-170.

DOI: https://doi.org/10.4038/tar.v25i2.8138

Ponrajah A.J.P. (1984). Design of Irrigation Systems for Small Catchments, $2^{\text {nd }}$ edition. Department of Irrigation, Colombo, Sri Lanka.

Rajapakse H.L., Inomata H. \& Fukami K. (2010). Diffuse source particulate-matter pollution modelling in a semiurbanized agricultural basin in Japan using process-based 
WEP and an erosion-transport model. Water Practice and Technology 5(3): wpt2010051.

DOI: https://doi.org/10.2166/wpt.2010.051

Silva E. (2004). Quality of irrigation water in Sri Lanka - status and trends. Asian Journal of Water, Environment and Pollution 1(1): 5-12.

United States Environmental Protection Agency (USEPA) (1976). Quality Criteria for Water. United States Environmental Protection Agency, Washington DC, USA.

United States Peace Corps (1980). United States Peace Corps Information Collection and Exchange (Online). Available at: http://www.nzdl.org/gsdlmod? $e=d-00000-00---o f f-0 c d l-$ -00-0----0-10-0---0---0direct-10---4------0-11--11-en-50--20-about---00-0-1-00-0--4----0-0-11-10-0utfZz-8-00\&a=$d \& c l=C L 1.36 \& d=H A S H d 437 e 4577406 c 1595 c d e 6 e .12$, Accessed 7 February 2017.

Walley F.L., Tomm G.O., Matus A., Slinkard A.E. \& Van Kessel C. (1996). Allocation and cycling of nitrogen in an alfalfa-bromegrass sward. Agronomy Journal 88: 834-843.

Wijesundara W.M.G.D., Nandasena K.A. \& Jayakody A.N. (2012). Spatial and temporal changes in N, P, K concentrations in water in the Thirappane Tank cascade in dry zone of Sri Lanka. Journal of Environmental Professionals Sri Lanka 1(1): 70-81.

DOI: https://doi.org/10.4038/jepsl.v1i1.5143

Wijesundara W.M.G.D., Nandasena K.A. \& Jayakody A.N. (2013). Seasonal and spatial variations of N, P, K and Cd concentrations in water of the Mahakanumulla cascade in the dry zone of Sri Lanka. Tropical Agricultural Research 24(3): 279-288.

DOI: https://doi.org/10.4038/tar.v24i3.8013

World Health Organization (WHO) (2011). Guidelines for Drinking Water Quality, $4^{\text {th }}$ edition. World Health Organization, Geneva, Switzerland.

Young S.M., Pitawala A. \& Gunatilake J. (2009). Effect of agricultural practices on chemical quality of water in Kala Oya river basin. Journal of Geological Society of Sri Lanka 13: $97-104$.

Zoysa D. \& Weerasinghe T. (2016). Study on the chemical and biological status of Malwathu Oya basin Anuradhapura in Sri Lanka. British Journal of Environmental Sciences 4(1): $1-10$. 